ISSN 1392-3196 / e-ISSN 2335-8947

Zemdirbyste-Agriculture, vol. 105, No. 3 (2018), p. 243-248

DOI 10.13080/z-a.2018.105.031

\title{
Effects of auxin analogues and heat stress on garden pea
}

\author{
Iskren SERGIEV ${ }^{1}$, Dessislava TODOROVA ${ }^{1}$, Elena SHOPOVA ${ }^{1}$, Jurga JANKAUSKIENE ${ }^{2}$, \\ Elžbieta JANKOVSKA-BORTKEVIČ², Sigita JURKONIENE ${ }^{2}$ \\ ${ }^{1}$ Institute of Plant Physiology and Genetics, Bulgarian Academy of Sciences \\ Acad. G. Bonchev 21, 1113 Sofia, Bulgaria \\ E-mail: dessita@bio21.bas.bg \\ ${ }^{2}$ Institute of Botany, Nature Research Centre \\ Akademijos 2, 08412 Vilnius, Lithuania
}

\begin{abstract}
The biochemical responses of high temperature (HT) stressed garden pea (Pisum sativum L.) pre-treated with the auxins 1-[2-chloroethoxycarbonyl-methyl]-4-naphthalenesulfonic acid calcium salt (TA-12) and 1-[2-dimethyla minoethoxicarbonylmethyl]naphthalene chlormethylate (TA-14) were studied. The HT stress caused an increase in lipid peroxidation in leaves indicating the occurrence of oxidative stress. The concentration of free proline and hydrogen peroxide $\left(\mathrm{H}_{2} \mathrm{O}_{2}\right)$ decreased, while the total phenolics, free thiols and the activity of catalase (CAT), superoxide dismutase (SOD) and guaiacol peroxidase (POX) were increased in the high temperature stressed plants. The pre-treatment with auxins mitigated the oxidative stress provoked by HT treatment. The favourable effect of these auxin-like compounds was interpreted in relation to their ability to counteract the oxidative stress caused by high temperature in pea plants. The auxin analogues maintained the concentrations of non-enzymatic antioxidants and the activities of defence enzymes scavenging reactive oxygen species to equal or near to normal physiological level. Based on the obtained data, we suggest that exogenous application of TA-12 and TA-14 alleviates the harmful effect of high temperature in pea.
\end{abstract}

Key words: antioxidant enzymes, auxin type compounds, high temperature stress, Pisum sativum, stress markers.

\section{Introduction}

The elevated air temperature is among the abiotic stress factors associated with climate change (Sita et al., 2017). Higher than the optimal air temperatures disturb the plant growth and these environmental conditions are regarded as high temperature (HT) stress (Kaushal et al., 2016; Bhandari et al., 2017; Sita et al., 2017). Extremely high temperatures induce accumulation of reactive oxygen species (ROS) which injure protein and nucleic acids structures and have deleterious effect on plant cell biomembranes (Awasthi et al., 2015; Kaushal et al., 2016). Therefore HT stress affects the overall plant growth and productivity through its negative influence on principal physiological and biochemical processes (Wahid et al., 2007; Hasanuzzaman et al., 2013; Kaushal et al., 2016; Bhandari et al., 2017; Fahad et al., 2017; Sita et al., 2017). Plant organisms have developed nonenzymatic and enzymatic defence systems (Kaushal et al., 2016; Szymańska et al., 2017; Czarnocka, Karpinski, 2018 ) to counteract the negative consequences of stresses including high temperature (Bhandari et al., 2017; Fahad et al., 2017). Plants react to unfavourable environmental factors through activation of some or all elements of the antioxidant defence system (Wahid et al., 2007; Bhandari et al., 2017).

Application of growth regulating substances can increase plant tolerance by influencing positively the plant defence system (Hasanuzzaman et al., 2013; Kaushal et al., 2016; Bhandari et al., 2017; Fahad et al., 2017). Auxins along with the other major classes of phytohormones involved in the control of diverse developmental processes play essential role in plant adaptive responses to a number of abiotic and biotic stresses (Kazan, 2013; Ahammed et al., 2016). The HT stress was reported to provoke an increase of endogenous auxin levels in different plant species like tobacco and cotton (Dobra et al., 2010; Min et al., 2014). In legumes and some other model crops, suppressed auxin biosynthesis and signalling in developing anthers were observed, resulting in pollen abnormalities (Ozga et al., 2017). The auxin physiological analogues 1-[2-chloroethoxycarbonylmethyl]-4-naphthalenesulfonic acid calcium salt (TA 12) and 1-[2-dimethylaminoethoxicarbonylmeth yl]naphthalene chlormethylate (TA-14) were reported to improve the cold acclimation and overwintering of oilseed rape (Velička et al., 2005; Anisimovienè et al.,

Please use the following format when citing the article:

Sergiev I., Todorova D., Shopova E., Jankauskienė J., Jankovska-Bortkevič E., Jurkonienė S. 2018. Effects of auxin analogues and heat stress on garden pea. Zemdirbyste-Agriculture, 105 (3): 243-248 DOI 10.13080/z-a.2018.105.031 
2008; Gavelienė et al., 2013) and develop benignant effect on physiological responses of UV-irradiated pea plants (Sergiev et al., 2017 a; b). The effects of these compounds have not been assessed against HT stress.

Garden pea is a broadly cultivated crop in Bulgaria. Increased temperatures during the reproductive phase can cause significant blossom losses of pea. The garden pea cultivar 'Ran-1'is characterized by shorter vegetation, early ripening and high productivity. This cultivar has been extensively grown for many years and is a certified standard for pea in Bulgaria. Recently we demonstrated that exogenous polyamine spermine had an alleviating effect against HT stress injury in pea plants (Todorova et al., 2016).

Here we report the protective effects of the auxins TA-12 and TA-14 on pea plants subjected to high temperature stress.

\section{Materials and methods}

Plant material and treatments. Garden pea (Pisum sativum L., cultivar 'Ran-1') was grown hydroponically during April 2016 and 2017. The growth conditions were $24 / 22^{\circ} \mathrm{C}$ day/night temperatures, $12 / 12 \mathrm{~h}$ photoperiod, $150 \mu \mathrm{mol} \mathrm{m} \mathrm{m}^{-2} \mathrm{~s}^{-1}$ photon flux density, and air humidity $80 \%$. Part of the plants at fully developed 3-4 leaf stage were treated with the auxins (TA) 1-[2-chloroethoxycarbonyl -methyl]-4naphthalenesulfonic acid calcium salt (TA-12) and 1-[2-dimethylaminoethoxicarbonylmethyl]naphthalene chlormethylate (TA-14). The compounds were applied by spraying of $1 \mathrm{mM}$ water solutions. Tween $80(0.01 \%)$ was used as a surfactant. The control plants were also sprayed with $0.01 \%$ solution of Tween 80 . After twenty four hours, part of the control and auxin treated plants were transferred to a high temperature (HT) chamber. The HT stress was applied for two days. During each day of the HT stress program, the temperature was progressively elevated from $22^{\circ} \mathrm{C}$ to $42^{\circ} \mathrm{C}$ (9:00 a.m. to 12:00 a.m.), which was maintained till 17:00 p.m. During the night, the temperature was decreased to $22^{\circ} \mathrm{C}$. The air humidity in the growth chamber was around $50 \%$. The rest of the control and TA-treated plants were kept under the initial growth conditions. Each experimental treatment consisted of 24 plants. When the stress program ended, the HT-treated plants were moved back to the initial growth conditions for recovery. Samples for measurements were collected from the $3^{\text {rd }}$ leaf pair from at least three plants. The biochemical analyses were done immediately after the HT stress $(0 \mathrm{~h})$, and at 24 and $96 \mathrm{~h}$ of the recovery period.

Biochemical analyses. Approximately $300 \mathrm{mg}$ of leaf material was ground with $0.1 \%(\mathrm{w} / \mathrm{v})$ trichloroacetic acid for determination of soluble phenols, free thiolcontaining compounds, free proline, hydrogen peroxide $\left(\mathrm{H}_{2} \mathrm{O}_{2}\right)$ and malondialdehyde (MDA). Total phenolics concentration was determined with Folin-Ciocalteu reagent. The absorbance was measured at $725 \mathrm{~nm}$ using gallic acid as a reference (Swain, Goldstein, 1964). Ellman's reagent was used for reading the absorbance at $412 \mathrm{~nm}$ of free thiol-containing compounds (Ellman, 1959). The concentration of free proline was determined according to Bates et al. (1973). The MDA concentration was measured following the procedure described by Kramer et al. (1991). The amount of $\mathrm{H}_{2} \mathrm{O}_{2}$ was measured according to Alexieva et al. (2001).
Approximately $200 \mathrm{mg}$ leaf sample was homogenized in $100 \mathrm{mM}$ potassium phosphate buffer ( $\mathrm{pH}$ 7.0) containing $1 \mathrm{mM}$ ethylenediaminetetraacetic acid (EDTA) and 1\% polyvinylpyrrolidone (w/v). The homogenates were centrifuged at $12000 \times g$ for $15 \mathrm{~min}$. The resulting supernatant was used for measurement of total protein and antioxidant enzyme activities. Total protein was determined according to the method of Bradford (1976). The catalase (CAT, EC 1.11.1.6) activity was measured by monitoring the absorbance decrease at $240 \mathrm{~nm}\left(\varepsilon=36.8 \mathrm{mM}^{-1} \mathrm{~cm}^{-1}\right)$ for $60 \mathrm{~s}$ Aebi (1984). Guaiacol peroxidase (POX, EC 1.11.1.7) activity was measured by using of guaiacol as an external electron donor and the absorbance increase at $470 \mathrm{~nm}$ $\left(\varepsilon=26.6 \mathrm{mM}^{-1} \mathrm{~cm}^{-1}\right)$ recorded for $60 \mathrm{~s}$ Dias and Kosta (1983). The superoxide dismutase (SOD, EC 1.15.1.1) activity was assayed by the method of Beauchamp and Fridovich (1971). The amount of SOD causing 50\% inhibition of the photochemical reduction at $560 \mathrm{~nm}$ of nitro blue tetrazolium (NBT) was defined as one unit.

Spectrophotometer Multiskan Spectrum (Thermo Fisher Scientific, Finland) was used for spectrophotometrical measurements. Spectrophotometer Shimadzu UV-1601 UV-Visible (Shimadzu, Japan) was used for kinetic assay of CAT and POX activities.

Statistical analysis. The results are from three independent experiments performed in triplicate. The data are mean values \pm standard error (SE). The Duncan's multiple range test was used to evaluate the significant differences at a level of 0.05 .

\section{Results}

The MDA concentration of stressed plants was significantly higher and remained constantly higher by $12 \%$ than the control during the recovery period (Fig. 1A). When the auxin physiological analogues (TA) were applied alone, MDA concentration was decreased by $5 \%$. At $96 \mathrm{~h}$ of recovery MDA content in TA-treated plants dropped to the control levels. The pre-treatment with TA-12 substantially reduced MDA in plants subjected to HT stress by $21 \%(0 \mathrm{~h}), 9 \%(24 \mathrm{~h})$ and $6 \%(96 \mathrm{~h})$. The application of TA-14 significantly decreased MDA content in HT-treated plants by $26 \%$ $(0 \mathrm{~h}), 14 \%(24 \mathrm{~h})$ and $6 \%(96 \mathrm{~h})$. All treatments reduced $\mathrm{H}_{2} \mathrm{O}_{2}$ concentration (Fig. 1B). Twenty-four hours after $\mathrm{HT}^{2}$ stress $\mathrm{H}_{2} \mathrm{O}_{2}$ decreased by $28 \%$ in stressed plants and by $32 \%$ at the last measurement point as compared to the respective controls. The levels of $\mathrm{H}_{2} \mathrm{O}_{2}$ in HT-stressed plants pre-treated with TA compounds, although lower than the control, remained above the ones measured in the plants subjected only to HT treatment (Fig. 1B).

Total protein concentration was increased (up to $18 \%$ above the control) by all treatments immediately after the HT stress (Fig. 2A). Twenty-four hours later there was no considerable alteration of protein concentration and this trend remained till the end of the experiment.

Immediately after the HT stress, SOD activity increased in all experimental treatments with higher levels detected in samples treated with TA or TA + HT (Fig. 2B). Later ( $24 \mathrm{~h}$ recovery after high temperature) an additional rise of SOD activity by $45 \%$ in plants subjected to high temperature was detected. At the last measurement the SOD activity remained higher (15\%) than the control only in HT-treated plants. The SOD activity of plants treated with TA compounds reached the control level. 


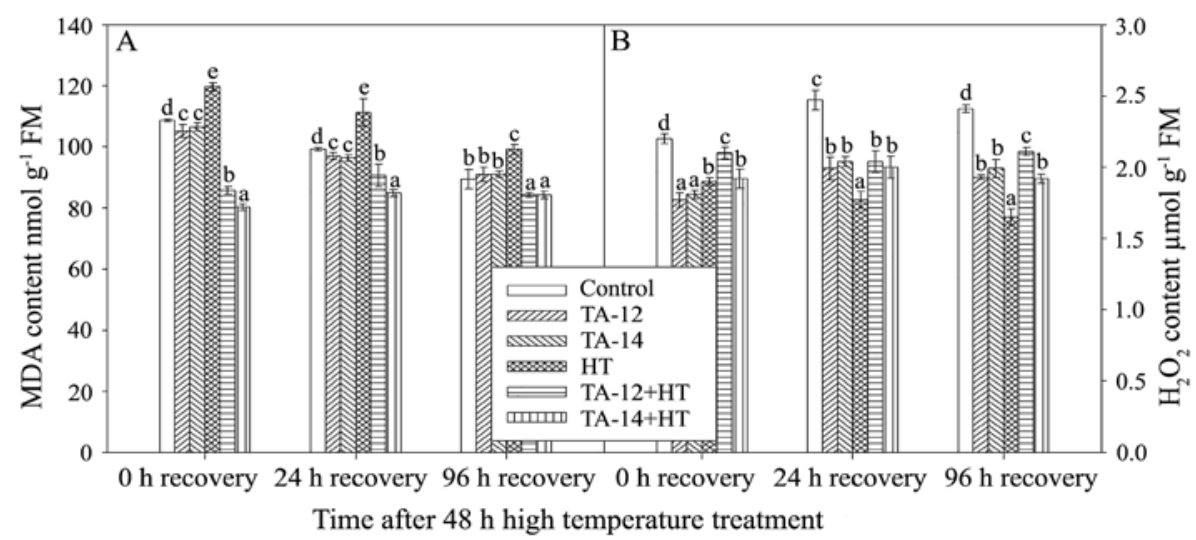

Note. Statistically significant $(p<0.05)$ difference between treatments are designated by different letters; FM - fresh mass.

Figure 1. Malondialdehyde (MDA) (A) and hydrogen peroxide $\left(\mathrm{H}_{2} \mathrm{O}_{2}\right)(\mathrm{B})$ concentration in garden pea sprayed with $1 \mathrm{mM}$ TA-12 or TA-14 and treated with high temperature (HT) for $48 \mathrm{~h}$

Initially, CAT activity in all TA-treated plants, both when the compounds were applied alone and in combination with high temperature, remained stable (Fig. 2C). Later, at the $96 \mathrm{~h}$ of recovery period, TA compounds provoked considerable decrease in CAT activity which was up to $55 \%$ below the control. HT treatment caused an increase in CAT activity by $29 \%$ over the control and this tendency persisted during the entire recovery period.
HT treatment increased POX activity by $20 \%$ (Fig. 2D). The enzymatic activity remained higher during the recovery period $(19 \%$ and $16 \%$, at 24 and $96 \mathrm{~h}$, respectively). Although the application of TA compounds led to considerable decrease (up to 27\%) in POX activity in plants subjected to HT stress at the first measurement point, later both auxin-like compounds did not cause significant changes in POX activity.

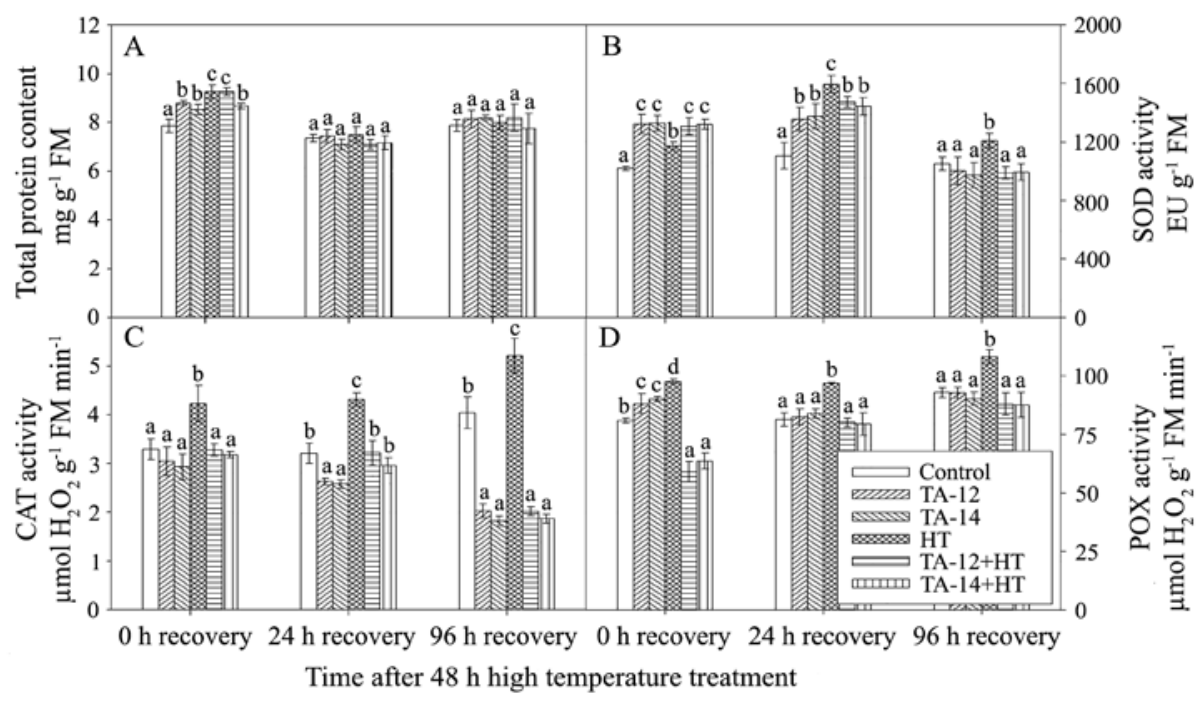

Note. Statistically significant $(p<0.05)$ difference between treatments are designated by different letters; FM - fresh mass.

Figure 2. Total protein concentration (A), superoxide dismutase (SOD) activity (B), catalase (CAT) activity (C) and guaiacol peroxidase (POX) activity (D) in garden pea sprayed with TA-12 or TA-14 and treated with high temperature (HT) for $48 \mathrm{~h}$

A decrease in free proline concentration by $18 \%$ after HT treatment was measured at $24 \mathrm{~h}$ of recovery and it remained lower than the control by $41 \%$ till the end of the recovery period (Fig. 3A). An increase in proline concentration was detected in plants sprayed with TA compounds during the first $24 \mathrm{~h}$ of recovery. Later at 96 $\mathrm{h}$, a decreased proline concentration was documented in all TA-treated plants. However, the proline level in plants pre-treated with TA remained higher than the one measured in HT-treated plants.

TA compounds did not cause any significant alterations in total phenolics concentration when applied alone during the entire experimental period (Fig. 3B). An increase in phenolics amount was detected in stressed plants, and it was 8,10 and $16 \%$. When combined with high temperature, both TA compounds also enhanced total phenolics concentration to levels close to the ones observed in HT-treated samples. At $96 \mathrm{~h}$ no differences in phenolics content between the single TA and combined TA + HT treatments were established.

Like total phenolics, both TA compounds did not cause any significant alterations in free thiols concentration when applied alone (Fig. 3C). The concentration of free thiols increased (by 11\%) in HT-treated plants immediately after heat stress, then it tended to decrease, and finally the amount was $7 \%$ below the control level. Both TA compounds maintained the thiol compounds at higher level than that measured in HT-treated plants. 


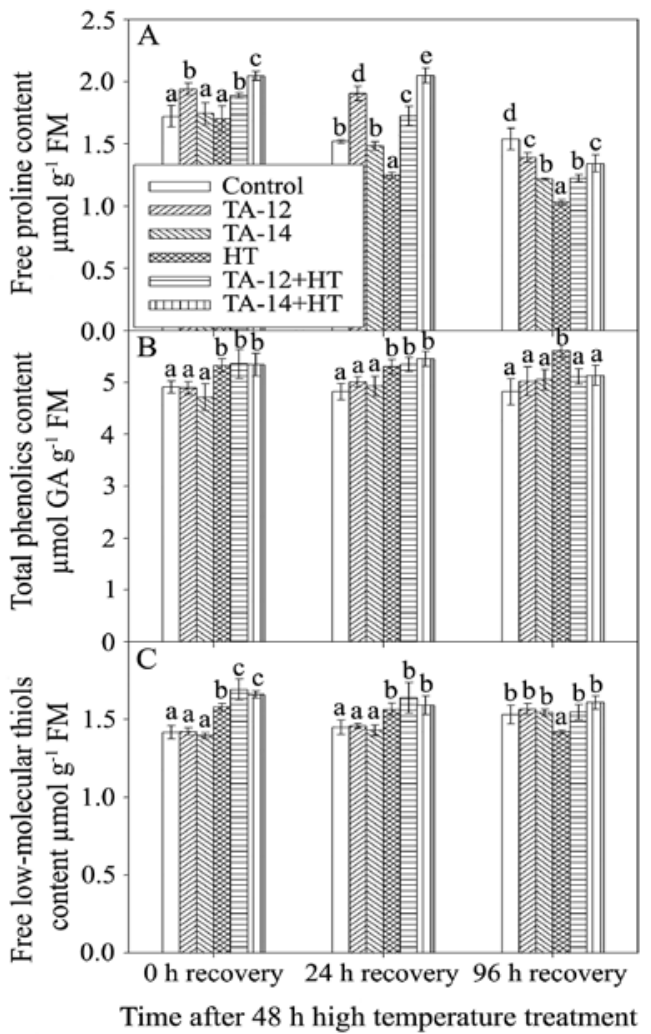

Note. Statistically significant $(p<0.05)$ difference between treatments are designated by different letters; FM - fresh mass, $\mathrm{GA}$ - gallic accid.

Figure 3. Free proline (A), total phenolics (B) and free low-molecular thiols (C) concentration in garden pea sprayed with TA-12 or TA-14 and treated with high temperature (HT) for $48 \mathrm{~h}$

\section{Discussion}

All abiotic stresses, including high temperature elicit ROS formation in plant cells (Gill, Tuteja, 2010; Awasthi et al., 2015; Bhandari et al., 2017; Szymańska et al., 2017). Overproduction of ROS damages cellular biomembranes which leads to the accumulation of MDA (Wahid et al., 2007; Bhandari et al., 2017; Fahad et al., 2017). We found an increase in MDA concentration after HT treatment and this is in agreement with the observation reported earlier for legume crops (Kumar et al., 2012 a; Todorova et al., 2016). Both TA compounds applied alone did not provoke MDA accumulation which suggested that application of these auxin physiological analogues did not damage cell biomembranes. Moreover, lower MDA concentration was detected in the combined treatment $(\mathrm{TA}+\mathrm{HT})$, which proved that exogenous TA compounds decreased the lipid peroxidation under HT stress. This suggests that the auxin-like compounds diminish damage to membrane integrity and assist plant to cope with the detrimental consequences of HT stress.

Hydrogen peroxide $\left(\mathrm{H}_{2} \mathrm{O}_{2}\right)$ is one of the ROS which is produced under optimal physiological and stress conditions. At optimum temperature, the level of $\mathrm{H}_{2} \mathrm{O}_{2}$ is physiologically balanced, while under stress conditions the overproduction of $\mathrm{H}_{2} \mathrm{O}_{2}$ is observed (Gill, Tuteja, 2010; Awasthi et al., 2015; Bhandari et al., 2017; Szymańska et al., 2017). We found that $\mathrm{H}_{2} \mathrm{O}_{2}$ concentration decreased considerably after all treatments and especially by high temperature. Along with its role as ROS, a certain portion of $\mathrm{H}_{2} \mathrm{O}_{2}$ participates in stress responses as signalling component. Since $\mathrm{H}_{2} \mathrm{O}_{2}$ has a relatively long half-life it is capable of serving as a long-distance signalling molecule (Ślesak et al., 2007; Czarnocka, Karpinski, 2018). Therefore, the substantial reduction of $\mathrm{H}_{2} \mathrm{O}_{2}$ observed under $\mathrm{HT}$ stress might disturb signal transduction and physiological stress responses in pea plants. Preliminary application of TA compounds prior to $\mathrm{HT}$ treatment kept the $\mathrm{H}_{2} \mathrm{O}_{2}$ concentration above that in HT-treated plants. It could be suggested that pretreatment with TA compounds restored partially $\mathrm{H}_{2} \mathrm{O}_{2}$ level in HT-treated plants.

Activities of major antioxidant enzymes SOD, CAT and POX were substantially induced in HT-treated individuals suggesting that plant defence was activated to cope with the ROS formed due to HT stress as reported earlier (Kumar et al., 2012 a; Hasanuzzaman et al., 2013; Awasthi et al., 2015; Ding et al., 2016; Todorova et al., 2016; Bhandari et al., 2017). The exogenous application of both TA compounds decreased the enzymatic activities measured in TA + HT-treated plants. It could be summarized that TA pre-treatment had positive effect on heat-stressed plants by keeping the $\mathrm{H}_{2} \mathrm{O}_{2}$ levels and the activities of the antioxidant enzymes (except in the case of CAT) closer to the control as compared to the HT-treated plants. As a result, the preliminary application of auxin-like compounds provided better physiological and biochemical status of HT-treated pea plants which facilitated the plant adaptation reactions to HT stress. The exact mechanism causing decreased $\mathrm{H}_{2} \mathrm{O}_{2}$ levels and suppressed CAT activity in TA-treated plants remains unknown but clearly the priming with auxin physiological analogues is able to mitigate oxidative damage in HT stressed plants as it was proposed earlier for other phytohormonal and chemical treatments (Larkindale, Huang, 2004; Bhandari et al., 2017).

Free proline, phenolics and low-molecular thiolcontaining compounds are part of the non-enzymatic antioxidant defence system in plants (Gill, Tuteja, 2010; Hasanuzzaman et al., 2013; Awasthi et al., 2015; Bhandari et al., 2017; Czarnocka, Karpinski, 2018).

We found that proline was decreased by HT treatment, suggesting a disturbed antioxidant plant defence. Previously Kumar et al. (2012 b) have reported that abscisic acid assisted accumulation of osmoprotectants, including proline, which increased high temperature tolerance of chickpeas. The higher proline concentration measured in TA + HT-treated pea seedlings could be regarded as evidence that application of auxinlike acting compounds ensures better adaptation to HT treatment.

Accumulation of plant phenolics and lowmolecular thiols (in particular glutathione - which is the major low-molecular SH-containing compound, according to Foyer and Noctor, 2005) under high temperature conditions could be considered as plant adaptation response as suggested earlier (Wahid et al., 2007; Awasthi et al., 2015). Our experiments confirmed that HT treatment increased phenolics and thiols especially during the first $24 \mathrm{~h}$ of recovery suggesting activated antioxidant machinery. Similar observations were made by Kumar et al. (2012 a) who found that nonenzymatic antioxidants increased in chickpeas subjected to HT stress. Meanwhile TA compounds alone do not alter the concentration of these antioxidants. In combination with high temperature they maintained levels equal or higher than those measured in HT-treated plants but at the end of the recovery period phenolics and thiols in the same treatment group were comparable to control 
ones. Taking into account the alterations of the assessed parameters in both HT-treated and pre-treated with auxin analogues it is obvious that high temperature disturbed the normal physiological processes, while we conclude that TA application has protective capacity against heat stress in pea since the parameters of HT-treated plants remained considerably different from the respective controls. In the TA-primed plants the protective role of the tested compounds was manifested by maintaining the concentration of non-enzymatic antioxidants and antioxidant enzyme activities of POX and SOD equal or close to the normal physiological levels at the end of the experiment. The favourable effects of the investigated auxins were evidenced also by decreased MDA content.

Although the precise mechanism of the protective action of TA compounds remains unknown, the presented data prove that this type of plant growth regulators holds a promising capacity to counteract the negative consequences of abiotic stress factors, including high temperatures.

\section{Conclusions}

1. High temperature (HT) stress caused a disturbance of pea metabolism manifested by enhanced lipid peroxidation; induced peroxidase (POX), catalase (CAT) and superoxide dismutase (SOD) activities, accompanied by decreased concentration of hydrogen peroxide $\left(\mathrm{H}_{2} \mathrm{O}_{2}\right)$ and free proline. High temperature provoked also an early increase of phenolics and thiols.

2. At the end of the experiment, most of the parameters measured in HT-treated garden pea (Pisum sativum L., cultivar 'Ran-1') failed to reach the control levels. Pre-treatment with the auxins facilitated the normalization of the monitored parameters (except CAT activity) which were close to the physiological levels in the controls.

3 . For the first time we have reported that pretreatment with the auxins 1-[2-chloroethoxycarbonylmethyl]-4-naphthalenesulfonic acid calcium salt (TA12) and 1-[2-dimethylaminoethoxicarbonylmethyl] naphthalene chlormethylate (TA-14) could lessen the negative physiological consequences of high temperature on pea plants.

\section{Acknowledgments}

The study was supported by the joint research project under the scientific agreement between Bulgarian Academy of Sciences and Lithuanian Academy of Sciences (2016-2018).

Received 08022018 Accepted 25062018

\section{References}

1. Aebi H. 1984. Catalase in vitro. Methods of Enzymology, 105: $121-126$ https://doi.org/10.1016/S0076-6879(84)05016-3

2. Ahammed G. J., Li X., Zhou J., Zhou Y.-H., Yu J.-Q. 2016. Role of hormones in plant adaptation to heat stress. Ahammed G. J., Yu J.-Q. (eds). Plant hormones under challenging environmental factors. Springer, p. 1-21. https://doi.org/10.1007/978-94-017-7758-2_1

3. Alexieva V., Sergiev I., Mapelli S., Karanov E. 2001. The effect of drought and ultraviolet radiation on growth and stress markers in pea and wheat. Plant, Cell and Environment, 24: 1337-1344.

https://doi.org/10.1046/j.1365-3040.2001.00778.x
4. Anisimovienė N., Jankauskienė J., Novickienė L. 2008. Actualities in plant cold acclimation. Sodininkystè ir daržininkystè, 27 (2): 99-109.

5. Awasthi R., Bhandari K., Nayyar H. 2015. Temperature stress and redox homeostasis in agricultural crops. Frontiers in Environmental Sciences, 3: 11. https://doi.org/10.3389/fenvs.2015.00011

6. Bates L. S., Waldren R. P., Teare J. D. 1973. Rapid determination for free proline for water stress studies. Plant and Soil, 39: 205-207.

https://doi.org/10.1007/BF00018060

7. Beauchamp C., Fridovich I. 1971. Superoxide dismutase: improved assay and an assay applicable to acrylamide gels. Analytical Biochemistry, 44: 276-287. https://doi.org/10.1016/0003-2697(71)90370-8

8. Bhandari K., Sharma K. D., Hanumantha Rao B., Siddique K. H. M., Gaur P., Agrawal S. K., Nair R. M., Nayyar H. 2017. Temperature sensitivity of food legumes: a physiological insight. Acta Physiologiae Plantarum, 39: 68. https://doi.org/10.1007/s11738-017-2361-5

9. Bradford M. 1976. A rapid and sensitive method for the quantification of microgram quantities of protein utilizing the principle of protein-dye binding. Analytical Biochemistry, 72: 248-254.

https://doi.org/10.1016/0003-2697(76)90527-3

10. Czarnocka W., Karpinski S. 2018. Friend or foe? Reactive oxygen species production, scavenging and signaling in plant response to environmental stresses. Free Radical Biology and Medicine https://doi.org/10.1016/j.freeradbiomed.2018.01.011

11. Dias M. A., Costa M. M. 1983. Effect of low salt concentrations on nitrate reductase and peroxidase of sugar beet leaves. Journal of Experimental Botany, 34: 537-543. https://doi.org/10.1093/jxb/34.5.537

12. Ding X., Jiang Y., Hao T., Jin H., Zhang H., He L., Zhou Q., Huang D., Hui D., Yu J. 2016. Effects of heat shock on photosynthetic properties, antioxidant enzyme activity, and downy mildew of cucumber (Cucumis sativus L.). PLoS ONE, 11 (4): e0152429. https://doi.org/10.1371/journal.pone.0152429

13. Dobra J., Motyka V., Dobrev P., Malbeck J., Prasil I. T., Haisel D., Gaudinova A., Havlova M., Gubis J., Vankova R. 2010. Comparison of hormonal responses to heat, drought and combined stress in tobacco plants with elevated proline content. Journal of Plant Physiology, 167: 1360-1370. https://doi.org/10.1016/j.jplph.2010.05.013

14. Ellman G. 1959. Tissue sulfhydryl groups. Archives of Biochemistry and Biophysics, 82: 70-77. https://doi.org/10.1016/0003-9861(59)90090-6

15. Fahad S., Bajwa A. A., Nazir U., Anjum S. A., Farooq A., Zohaib A., Sadia S., Nasim W., Adkins S., Saud S., Ihsan M. Z., Alharby H., Wu C., Wang D., Huang J. 2017. Crop production under drought and heat stress: plant responses and management options. Frontiers in Plant Science, 8: 1147 . https://doi.org/10.3389/fpls.2017.01147

16. Foyer C., Noctor G. 2005. Oxidant and antioxidant signalling in plants: a re-evaluation of the concept of oxidative stress in a physiological context. Plant Cell and Environment, 28 (8): 1056-1071. https://doi.org/10.1111/j.1365-3040.2005.01327.x

17. Gavelienė V., Novickienė L., Pakalniškytė L. 2013. Effect of auxin physiological analogues on rapeseed (Brassica napus) cold hardening, seed yield and quality. Journal of Plant Research, 126: 283-292. https://doi.org/10.1007/s10265-012-0525-3

18. Gill S., Tuteja N. 2010. Reactive oxygen species and antioxidant machinery in abiotic stress tolerance in crop plants. Plant Physiology and Biochemistry, 48: 909-930. https://doi.org/10.1016/j.plaphy.2010.08.016

19. Hasanuzzaman M., Nahar K., Alam M. M., Roychowdhury R., Fujita M. 2013. Physiological, biochemical, and molecular mechanisms of heat stress tolerance in plants. International Journal of Molecular Science, 14: 9643-9684. https://doi.org/10.3390/ijms14059643 
20. Kaushal N., Bhandari K., Siddique K. H. M., Nayyar H. 2016. Food crops face rising temperatures: an overview of responses, adaptive mechanisms, and approaches to improve heat tolerance. Cogent Food and Agriculture, 2: 1134380. https://doi.org/10.1080/23311932.2015.1134380

21. Kazan K. 2013. Auxin and the integration of environmental signals into plant root development. Annals of Botany, 112: 1655-1665. https://doi.org/10.1093/aob/met229

22. Kramer G., Norman H., Krizek D., Mirecki R. 1991. Influence of UV-B radiation on polyamines, lipid peroxidation and membrane lipids in cucumber. Phytochemistry, 30: 2101-2108. https://doi.org/10.1016/0031-9422(91)83595-C

23. Kumar S., Thakur P., Kaushal N., Malik J. A., Gaur P., Nayyar H. 2012 (a). Effect of varying high temperatures during reproductive growth on reproductive function, oxidative stress and seed yield in chickpea genotypes differing in heat sensitivity. Archives of Agronomy and Soil Science, 59: 823-843.

https://doi.org/10.1080/03650340.2012.683424

24. Kumar S., Kaushal N., Nayyar H., Gaur P. 2012 (b). Abscisic acid induces heat tolerance in chickpea (Cicer arietinum L.) seedlings by facilitated accumulation of osmoprotectants. Acta Physiologiae Plantarum, 34: 1651-1658. https://doi.org/10.1007/s11738-012-0959-1

25. Larkindale J., Huang B. 2004. Thermotolerance and antioxidant systems in Agrostis stolonifera: Involvement of salicylic acid, abscisic acid, calcium, hydrogen peroxide, and ethylene. Journal of Plant Physiology, 161: 405-413. https://doi.org/10.1078/0176-1617-01239

26. Min L., Li Y., Hu Q., Zhu L., Gao W., Wu Y., Ding Y., Liu S., Yang X., Zhang X. 2014. Sugar and auxin signaling pathways respond to high-temperature stress during anther development as revealed by transcript profiling analysis in cotton. Plant Physiology, 164: 1293-1308. https://doi.org/10.1104/pp.113.232314

27. Ozga J. A., Kaur H., Savada R. P., Reinecke D. M. 2017. Hormonal regulation of reproductive growth under normal and heat-stress conditions in legume and other model crop species. Journal of Experimental Botany, 68: 1885-1894.

28. Sergiev I., Todorova D., Shopova E., Katerova Z., Jankauskiene J., Jurkoniene S. 2017 (a). Auxin-like compounds act as protectors against UV-B irradiation in garden pea plants. Botanica Lithuanica, 23 (2): 79-88. https://doi.org/10.1515/botlit-2017-0010

29. Sergiev I., Todorova D., Katerova Z., Shopova E., Jankauskiene J., Jurkoniene S. 2017 (b). Beneficial effects of auxin-like compounds on pea plants irradiated with UV-C. Genetics and Plant Physiology, 7 (3-4): 135-146.

30. Sita K., Sehgal A., Hanumantha Rao B., Nair R M., Vara Prasad P. V., Kumar S., Gaur P. M., Farooq M., Siddique K. H. M., Varshney R. K., Nayyar H. 2017. Food legumes and rising temperatures: effects, adaptive functional mechanisms specific to reproductive growth stage and strategies to improve heat tolerance. Frontiers in Plant Science, 8: 1658. https://doi.org/10.3389/fpls.2017.01658

31. Ślesak I., Libik M., Karpinska B., Karpinski S., Miszalski Z. 2007. The role of hydrogen peroxide in regulation of plant metabolism and cellular signalling in response to environmental stresses. Acta Biochimica Polonica, 54: 39-50.

32. Swain T., Goldstein J. L. 1964. The quantitative analyses of phenolic compounds. Pridham J. B. (ed.). Methods in polyphenol chemistry. Oxford, UK, p. 131-146.

33. Szymańska R., Ślesak I., Orzechowska A., Kruk J. 2017. Physiological and biochemical responses to high light and temperature stress in plants. Environmental and Experimental Botany, 139: 165-177. https://doi.org/10.1016/j.envexpbot.2017.05.002

34. Todorova D., Katerova Z., Shopova E., Jodinskiene M., Jurkoniene S., Sergiev I. 2016. Responses of garden pea (Pisum sativum L.) plants to heat stress and spermine treatment. Zemdirbyste-Agriculture, 103 (1): 99-106. https://doi.org/10.13080/z-a.2016.103.013

35. Velička R., Rimkevičienè M., Novickienè L., Anisimovienè N., Brazauskienè I. 2005. Improvement of oil rape hardening and frost tolerance. Russian Journal of Plant Physiology, 52 (4): 473-480. https://doi.org/10.1007/s11183-005-0070-1

36. Wahid A., Gelani S., Ashraf M., Foolad M. R. 2007. Heat tolerance in plants: an overview. Environmental and Experimental Botany, 61: 199-223.

https://doi.org/10.1016/j.envexpbot.2007.05.011

ISSN 1392-3196 / e-ISSN 2335-8947

Zemdirbyste-Agriculture, vol. 105, No. 3 (2018), p. 243-248

DOI 10.13080/z-a.2018.105.031

\title{
Auksino analogų ir karščio streso poveikis žirniams
}

\author{
I. Sergiev ${ }^{1}$, D. Todorova ${ }^{1}$, E. Shopova ${ }^{1}$, J. Jankauskiené ${ }^{2}$, E. Jankovska-Bortkevič², S. Jurkonienè $\dot{e}^{2}$ \\ ${ }^{1}$ Bulgarijos mokslų akademijos Augalų fiziologijos ir genetikos institutas \\ ${ }^{2}$ Gamtos tyrimų centro Botanikos institutas
}

\section{Santrauka}

Tiriant auksinais paveikto sejjamo žirnio (Pisum sativum L.) biocheminị atsaką ị aukštą temperatūrą, augalai buvo paveikti 1-[2-chloretoksikarbonil-metil]-4-naftalinsulfo rūgšties kalcio druska (TA-12) ir 1-[2-dimetilaminoetoksikarbonilmetil]naftilchlormetano rūgštimi (TA-14). Karščio stresas padidino lapų lipidų peroksidacijos lygị, kuris rodo esant oksidacinį stresą. Aukšta temperatūra paveiktuose augaluose sumažejo laisvojo prolino ir vandenilio peroksido $\left(\mathrm{H}_{2} \mathrm{O}_{2}\right)$ koncentracija ir padidejo suminis fenolinių junginių, laisvujų tiolių bei katalazès, superoksido dismutazės ir gvajakolio peroksidazès aktyvumas. Karščio sukeltas oksidacinis stresas buvo sušvelnintas augalus paveikus auksinais. Teigiamas auksino junginių poveikis gali būti paaiškintas jų gebėjimu neutralizuoti aukštos temperatūros sukeltą oksidacini stresą žirniams. Auksino analogai palaiko toki pat arba labai artimą nefermentinių antioksidantų koncentracijų ir fermentų, neutralizuojančių reaktyvias deguonies formas, aktyvumo fiziologini lygị. Tyrimo duomenimis, egzogeninis TA-12 ir TA-14 poveikis sumažina žalingą aukštos temperatūros poveikị žirniams.

Reikšminiai žodžiai: antioksidantiniai fermentai, auksino junginiai, aukštos temperatūros stresas, Pisum sativum, streso žymekliai. 